\title{
ОЗНАКЕ ЗА „СЛИЧНОСТ” И „ЕДНАКОСТ” У СЛОВЕНСКИМ ЈЕЗИЦИМА И ПОЈМОВИ (ПРЕДСТАВЕ) НА КОЈИМА СЕ ОНЕ ЗАСНИВАЈУ (У КОМПАРАТИВНОМ РАСВЕТЉЕЫУ)
}

Мој стари учитељ, професор Олаф Брок [Broch], споменуо ми је једанпут да би интересантно било саставити преглед појмова или представа, на којима се заснивају ознаке за „сличност” и ,једнакост” у словенским језицима. Покушаћу у овом кратком реферату то да урадим.

По мом мишљењу, ови основни појмови су следећи (наведене темељне (кључне) речи дају се, по могућности, у староцрквенословенском (стцсл.) облику и у латиничкој транслитерацији):

1) „згодан за, подесан за, удобан, одговарајући”. Темељне речи: doba и $l i k z$.

а) Из именице доба „(згодно) време”, „повољна прилика” и сл. изведен је стцсл. придев подобънъ. Овај придев је најчешће превод грч. о̆ $\mu$ ою „сличан”; за пример можемо узети једну познату причу Исусову, Матеј 13, 31: подобъно јесть цесарьствије небесьскоје зръну горушъну о $\mu о i ́ \alpha$

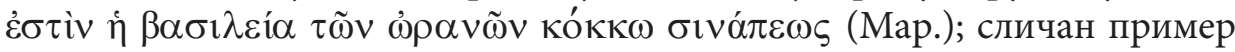
имамо код Луке 13, 18-19. Овамо спада такође глагол уподобити се, грч.

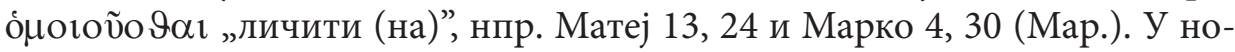
вијем црквенословенском језику налазе се слични примери.

Придев подобънъ у стцсл. се налази такође у значењу „повољан”,

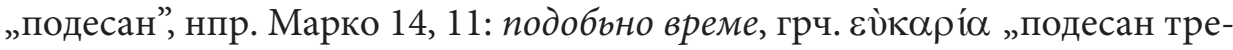
нутак, подесна прилика". Упореди, што се тиче значења, руск. удобный.

Придев подобьнъ налази се даље, mutatis mutandis, у каснијим словенским језицима, обично са значењем „сличан”, а понекад и у нешто друкчијим значењима, који одговарају различним значењима темељне речи доба: буг. подобен редовно значи „сличан”, док је схрв. подобан необичан у овом значењу; схрв. подобан најчешће значи „способан, леп, пристојан”. То важи и за словеначки podoben. На чешком и словачком 
podobný значи „сличан”, али на чешком ова се реч употребљава за слабији степен сличности, готово као немачки ähnlich, супротно stejný „gleich”, на које ћемо се касније вратити. Пољско podobny, руско подобный и украјинско подибный једна је од више речи, које значе „сличан, налик (на)”.

б) Друга темељна реч у овој групи појмова јесте $l i k z$, коју налазимо у неколико словенских језика са значењима „лице, образ, слика, фигура”; у стцсл. имамо изведеницу тице „изглед, лице”.

Из именице ликъ изведен је цсл. придев съличьнъ „сличан” (управо „који има облик заједно с неким (нечим)”); у цсл. он се јавља тек у нешто каснијим текстовима. У новијим словенским језицима ова реч, чини ми се, ограничена је на јужнословенске језике: схрв. сличан (у истом значењу такође схрв. налик (на)); макед. сличен, буг. (с нешто другачијим обликом) приличен. Одговарајући схрв. глагол обично је личити, словеначки sličiti (док словеначки ličiti значи „красити, китити, полирати”); на буг. „личити” гласи приличам.

Чешки sličný и пољски śliczny немају значења „сличан”, него „леп, љубак”; на руском ретка реч сличный значи „хармоничан” (према Павловском).

Неки научници, као нпр. Херман Хирт, мислили су да је именица ликъ позајмљеница из германскога, дакле да је иста реч с готским leik, н., норв. lik „мртво тело” итд., или да је прасродна са овим речима. Млађи се научници, као Макс Фасмер (Max Vasmer), Петар Скок, не слажу с овим мишљењем; они чак и не рачунају са утицајем германскога (готск. galeiks, нем. gleich, старонорд. glik $r\left(l_{i} k r\right)$ кад је у питању придев схрв. сличан, словеначки sličen итд., иако ове словенске речи тачно одговарају споменутим германским речима, не само по форми, него и по значењу („који има облик заједно с неким (нечим)"). Ја нисам етимолог и не бих хтео да износим било какво лично мишљење о овом питању. Али ако су у праву поменути млађи научници, они свакако треба да претпоставе паралелан развитак у словенском и германском. Допуштам себи, ипак, да наговестим једну другу могућност: у касном латинском постоји придев conformîs са значењем „сличан”. А Словени, када су се населили на Балкан, могли су ову реч, conformis, моделирати у одговарајући облик съличьнъ, који имамо у схрв. сличан итд.; ово се схватање подупире чињеницом да се реч сличан итд. у значењу „similis” налази само код Јужних Словена. Са других подручја, такође, могу се навести примери таквог продирања културних појава из класичне старине на словенски Балкан. Спомињем, нпр., римски пролећни празник rosalia, који се појављује код Срба као такозване русаље, једна церемонија у време Тројице, када се жене, у неким српским селима, предају екстатичним оргијама. Југословенски ет- 
нолози тврде да се ова церемонија из Италије пренела међу балканске народе, а да су је од њих прихватили досељени Словени. Одговарајуће церемоније налазе се у извесним пределима Бугарске и северне Грчке, и сматра се да оне произлазе од старог Дионисова култа.

У случају да се не би могло одржати објашњење речи съличьнъ као калкирано латинско conformis, требало би и тада рачунати са паралелним развитком.

Споменуо сам да чешки sličný, пољски śliczny и руски сличный имају значење „леп, хармоничан”. У вези с овим интересантно је да наш нордијски придев lik „сличан” такође може да има такво значење. Када се каже нпр.: jeg tok det likeste jeg fant, то би значило „узео сам то, што је било најподесније, најповољније”. А норв. глагол å like noe „волети нешто” етимолошки је сродан с придевом lik „сличан”; тај је глагол првобитно био безличан: старонорв. eitt líkar mér vel „нешто ми се јако свиђа”.

2) Други је основни појам:

„који ходи заједно с неким (нечим)”. Темељне речи: hodъ, hoditi.

Изведенице из ових речи ограничене су, очигледно, на јужнословенске и источнословенске језике: буг. сходен, сходство, глагол схождам се; схрв. сходан, сходност. Руске речи похожий, сходный, сходство (у простом руском језику такође придев схожыц̆) имају све, према руским синонимним речницима, готово истоветна значења; у украјинском имамо похожый, схожыц̆. Ових изведеница, чини се, нема у стцсл.

У ову појмовну сферу („идење, хођење”) спада исто тако схрв. поnym (предлог с генитивом) „слично, као што”; последњи део ове речи је nуm „цеста, друм”.

3) Трећи је основни појам:

„који је једне врсте, једноврстан”. Темељна реч: jedinokovъ.

Ова реч има своје пандане у другим словенским језицима, који обично означавају високи степен сличности и приближавају се значењу „Истоветан, идентичан, исти”; упор. нем. eins und dasselbe, норв. ett og det samme „једно те исто”. Буг. има еднаков, схрв. једнак и глагол једначити, словеначки enak, чешки и словачки jednaký, пољски jednaki, руск. одинаковыц , укр. однаковый.

Корисно је упоредити ове речи са одговарајућим речима у класичним језицима. Грч. придев оцоюь „сличан” сродан је са о̊ ки, исти”; о́ о́ које су опет сродне с лат. semel „једанпут”, simul „истовремено” (старолат. 
semul), simulare „једначити, подражавати”, с франц. sembler „чинити се”, ressembler „личити на” итд.

У германским језицима једна паралела јесте нпр. наш норв. придев ens (и ensartet) „једноврстан”; овамо спада такође нем. придев ähnlich, мада модерни правопис прикрива стварни однос. Лутер га пише enlich, a иначе је у средњонемачком обично einlich или ainlich.

4) Четврти је основни појам:

„раван, који је на истој равнини”, „истовредан”. Темељна реч: ravbnz.

Стцсл. равънъ преводи не само грч. $\dot{\mu} \alpha \lambda o ́ \varsigma$ „раван (конкретно)”,

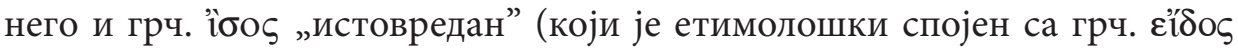
„изглед, форма, идеја” и са слов. видъ). Исту двострукост у нијансама значења налазимо у другим словенским језицима: буг. равен, схрв. paван, словеначки raven, чешк. rovný, словачки rovnaký, пољски równy. Руск. ровный има конкретно значење, док руск. равный (са цсл. вокализмом) значи „истовредан, једнак”; укр. ривный има оба значења.

5) Пети је основни појам:

„сталан, непоколебљив, који остаје исти”. Темељне речи: стајати, стајьнъ.

Овај основни појам налази се само у чешк. stejný (старочешк. stajný) „сасвим сличан, једнак”, док чешк. podobný има значење слабијег степена сличности.

6) „Као”. На крају треба споменути да се значење „сличан” каткад изражава речју истог садржаја с лат. „sicut”, нем. „gleichwie” нпр. буг. като, схрв. као.

Вук Караџић, у свом гипком преводу Библије, има нпр. у Матеја 13, 24: царство је небеско као човјек који посија добро сјеме у пољу својему.

У закључку можемо, дакле, казати да је облик podobьnъ итд. распрострањен по целом словенском подручју, søličъnъ итд. углавном је ограничен на јужнословенске језике, pohoži на источнословенске, shodnyj итд. на источнословенске и јужнословенске језике, jedinakovъ итд. налазимо по целом словенском подручју, исто као и равънъ итд., док је stejný изолиран у чешком. Уосталом, сви ови феномени могли би се изложити мрежом изоглоса. 
Arne Gallis

DIE BEZEICHNUNGEN FÜR, „GLEICHHEIT” IN DEN SLAVISCHE SPRACHEN UND DIE IHNEN ZUGRUNDELIEGENDEN BEGRIFFE (VORSTELLUNGEN) - IN KOMPARATIVER BELEUCHTUNG

\section{Zusammenfassung}

Die Begriffe oder Vorstellungen, welche den Bezeichnungen für "gleich, Gleichheit" in den slavischen Sprachen zugrunde liegen, sind in der Hauptsache die folgenden (die Schlüsselwörter sind, soweit möglich, in der altksl. Form angegeben):

1) "geeignet, passend, entsprechend". Schlüsselwörter: doba und likz. Beispiele: altksl. podobrnz und sbličbnz.

2) „(gutes) Zusammengehen”. Schlüsselwörter: chodz, choditi. Beispiele: russ. pochožij, schodnyj.

3) „einerlei, ein und derselbe”. Schlüsselwort: jedinakovo.

4) „eben, flach, im selben Plan befindlich, ebenbürtig”. Schlüsselwort: ravbnz.

5) "fest, unerschütterlich". Schlüsselwort: stajati. Beispiele: tschech. stejný.

6) "gleichwie”. Beispiele: bulg. kato, skr. kao.

Zusammenfassend kann gesagt werden, dass padobınz usw. über ganze slavische Gebiet verbreitet ist; søličın vischen Sprachen begrenzt, pochožij auf die ostslavischen, schodnyj usw. auf die ostslavischen und südslavischen Sprachen, jedinakovø usw. finden wir auf dem ganzen slavischen Gebiet, ebenso ravınz usw., während das tschechische stejný isoliert dasteht. Alle diese Phänomene können also, wenn man will, durch ein Netz von Isoglossen dargestellt werden.

Erleuchtende Parallelen aus anderen, nichtslavischen Sprachen werden im Referate gegeben. 